\title{
Metoda Pengurangan Zat Besi Dan Mangan Menggunakan Filter Bertingkat Dengan Penambahan UV Sterilizer Skala Rumah Tangga
}

\author{
Arief Muliawan', Rizki Ilmianih ${ }^{2}$ \\ ${ }^{1}$ Sekolah Tinggi Teknologi Bontang, Jln. Ir. H. Juanda No. 73, Bontang \\ ${ }^{2}$ Akademi Farmasi Bina Farmasi,Jln. Towua No. 114, Palu \\ ariefstitek@gmail.com¹,rizkiilmianih@gmail.com²
}

\begin{abstract}
ABSTRAK. Air tanah pada umumnya mengandung zat besi (Fe) dan Mangan (Mn) cukup besar. Adanya Kandungan Fe dan Mn dalam air ditandai dengan adanya perubahan fisis yaitu ditunjukan dengan perubahan warna air menjadi kuning-coklat setelah terjadi oksidasi. Dalam proses pengolahan air tanah menjadi air bersih telah mengurangi kadar zat besi dan mangan. Pengolahan air bersih menjadi air minum perlu dilakukan dengan mengunakan filter air sehingga diperoleh hasilkeluaran dibawah ambang batas perundangan. Telah dilakukan pembuatan alat filter bertingkat dengan menggunakan batu kerikil, pasir silika, karbon aktif, dan Manganese Dioxide. Keluaran hasil filter dilengkapi dengan sinar UV sterilizer yang berfungsi sebagai pembunuh kuman. Hasil yang diperoleh kadar besi $(\mathrm{Fe})$ menjadi $0,28 \mathrm{mg} / \mathrm{l}$ yang semula $8,6 \mathrm{mg} / \mathrm{l}$, kadar mangan $0,15 \mathrm{mg} / \mathrm{l}$ yang semula 4,8 mg/l dan kadar kekeruhan 4,01 NTU yang semula 9,73 NTU. Pada proses filtrasi ini belum mampu untuk menghilangkan bakteri E.coli dimana masih berkisar lebih dari $1600 \mathrm{MPN} / \mathrm{ml}$. Pada tahap ketiga dari filter ini dengan penambahan catridge dan sinar UV tampak bahwa bakteri E.Coli telah mati. Pada tahap ketiga dari pembuatan alat filter ini pula diperoleh kadar besi (Fe) 0,086 mg/l, mangan (Mn) 0,06 mg/l, dan kekeruhan 1,56 NTU. Nilai dari ke empat parameter yakni kekeruhan, besi $(\mathrm{Fe})$, mangan $(\mathrm{Mn})$ dan bakteri E.coli telah dibawah standar baku mutu air yang dipersyaratkan untuk komsumsi.
\end{abstract}

Kata kunci : Filter Air, besi, mangan, Sinar UV.

\begin{abstract}
Ground water generally contains iron (Fe) and Manganese (Mn) is quite large. Their content of $\mathrm{Fe}$ and $\mathrm{Mn}$ in the water marked by physical changes are indicated by changes in water color to yellow-brown after oxidation. The processing of ground water into clean water have reduced levels of iron and manganese. Clean water into drinking water needs to be done by using a water filter so obtained hasilkeluaran below the threshold of legislation. Have been fabricated by using the filter tool graded gravel, silica sand, activated carbon, and Manganese Dioxide. The output of the filter is equipped with a UV light sterilizer that serves as a germ killer. Results obtained levels of iron ( $\mathrm{Fe}$ ) to 0.28 $\mathrm{mg} / \mathrm{l}$ which was originally $8.6 \mathrm{mg} / \mathrm{l}$, the manganese content of $0.15 \mathrm{mg} / \mathrm{l}$ which was originally $4.8 \mathrm{mg} / \mathrm{l}$ and $4.01 \mathrm{NTU}$ turbidity levels were originally 9,73 NTU. In this filtration process has been unable to eliminate the bacterium E.coli which is still around more than $1600 \mathrm{MPN} / \mathrm{ml}$. In the third phase of the filter cartridge and with the addition of $U V$ rays it appears that E. coli bacteria are dead. In the third stage of the manufacture of the filter tool is also obtainable levels of iron ( $\mathrm{Fe}$ ) $0.086 \mathrm{mg} / \mathrm{l}$, manganese (Mn) $0.06 \mathrm{mg} /$ $l$, and the turbidity of $1.56 \mathrm{NTU}$. Values of the four parameters such as turbidity, iron (Fe), manganese (Mn) and E. coli bacteria had been below water quality standards required for consumption.
\end{abstract}

Keywords : Air Filter, iron, manganese, UV rays.

\section{PENDAHULUAN}

Laju pertumbuhan penduduk yang cukup tinggi setiap tahun serta percepatan perkembangan pembangunan terjadi di kota besar menyebabkan peningkatan kebutuhan pelayanan infrastruktur yang sangat besar termasuk pelayanan air minum. Untuk mempercepat peningkatan pelayanan air minum memerlukan dana yang tidak sedikit, sedangkan kemampuan perusahaan Air Minum sangat terbatas. Sementara jumlah air tanah sekarang sangat terbatas 
diperkotaan [1]. Pemakaian air rawa sebagai sumber air untuk keperluan domestik dibeberapa kota bergambut menjadi alternatif pilihan terakhir [2].

Air bersih dan air layak minum adalah dua hal yang tidak sama. Tidak semua air bersih layak diminum, tetapi air layak minum biasanya berasal dari air bersih. Air bersih biasanya perlu diolah dahulu agar layak minum dan menjadi air minum dan menjadi air minum sehat. Air minum adalah air yang digunakan untuk komsumsi manusia [3].

Menurut Dapertemen Kesehatan, syarat-syarat air minum adalah tidak berasa, tidak berbau, tidak berwarna, tidak keruh, tidak mengandung mikro-organisme yang berbahaya dan tidak mengandung logam-logam berat atau senyawa tertentu yang melebihi batas persyaratan. Di indonesia pelayanan air bersih dalam skala besar masih terpusat di daerah perkotaan dan dikelola oleh Perusahaan Daerah Air Minum (PDAM) kota yang bersangkutan. Pelayanan penyediaan air bersih secara nasional masih jauh dari mencukupi dan dapat dikatakan relatif kecil yakni $16.08 \%{ }^{[4]}$. Untuk daerah yang belum mendapatkan pelayanan air bersih dari PAM umumnya mereka menggunakan air tanah (sumur), air sungai, air hujan, air sumber (mata air) dan lainya.

Air tanah pada umumnya mengandung zat besi (Fe) dan Mangan (Mn) cukup besar. Adanya Kandungan $\mathrm{Fe}$ dan $\mathrm{Mn}$ dalam air ditandai dengan adanya perubahan fisis yaitu ditunjukan dengan perubahan warna air menjadi kuning-coklat setelah terjadi oksidasi yaitu beberapa saat kontak dengan udara. Disamping dapat mengganggu kesehatan juga menimbulkan bau yang kurang enak serta menyebabkan warna kuning pada dinding bak serta bercak-bercak kuning pada pakaian. Oleh karena itu menurut PP No. 20 Tahun 1990 tersebut, kadar (Fe) dalam air minum maksimum yang diperbolehkan adalah $0,3 \mathrm{mg} / \mathrm{lt}$ dan kadar Mangan (Mn) dalam air minum yang diperbolehkan adalah $0,1 \mathrm{mg} / \mathrm{lt}$.

Untuk menghilangkan zat besi atau mangan di dalam air yang paling sering digunakan adalah dengan cara oksidasi yang diikuti proses pemisahan padatan (suspended solids). Mangan lebih sulit dioksidasi dari pada besi. Hal ini menyebabkan karena kecepatan oksidasi mangan lebih rendah dibanding dengan kecepatan oksidasi besi [5]. Ada beberapa cara oksidasi besi atau mangan yang paling sering digunakan dalam industri pengolahan air minum antara lain yakni proses aerasi-fitrasi, proses khlorinasi-fitrasi dan proses oksidasi kalium permanganat-fitrasi dengan mangan zeolit [6]. Pemilihan proses tersebut dipilih berdasarkan berdasarkan besarnya konsentrasi zat besi atau mangan serta konsisi air baku yang digunakan.

Air bersih yang yang bersumber dari Perusahaan daerah Air Minum (PDAM) terkadang masih memiliki endapan besi dan mangan dalam konsentrasi yang kecil. Pengolahan air bersih ini hingga zat besi dan mangan dalam air dapat diperkecil dengan cara mengunakan filter air yang dapat dibuat sendiri seperti penambahan zeolit pada filter [7], serta penggunaan karbon aktif sebagai media keramik filter ganda [8]. Penurunan kadar besi dan mangan dapat pula dilakukan dengan radiasi ultraviolet. Disamping dapat menurunkan kadar besi dan mangan, radiasi ultraviolet dapat juga menginaktivikasi mikroorganisme $[9,10]$. Sehingga dalam penelitian ini akan dikembangkan filter bertingkat yang dilengkapi dengan radiasi ultraviolet yang mampu mengendalikan penurunan zat besi dan mangan.

\title{
METODE DAN BAHAN
}

\author{
Alat dan Bahan \\ Alat dan bahan yang diperunakan dalam penelitian ini ialah Alat yang digunakan dalam \\ penelitian ini seperti gergaji besi, bor dan mata bor, lem pipa PVC, isolasi pipa, kunci \\ Inggris

\section{Proses Pembuatan} \\ Setelah alat dan bahan dikumpulkan akan dilakukan pembuatan peralatan sebagai berikut: \\ - Pipa PVC 4" dipotong dengan panjang 1,3 meter \\ - Pada salah satu sisi yang sama PVC 4" tersebut dibuat lubang seperti pada gambar berikut \\ - Selanjutnya dibuat satu buah lubang pada sisi yang sama (tegak lurus pusat lubang untuk \\ $\mathrm{C}_{\mathrm{O}}$ ). Jarak pusat masing-masing $10 \mathrm{~cm}$ dari ujung pipa bagian bawah, diameter lubang \pm 1
}


inchi. Lubang ini untuk memasang fiting untuk pipa air olahan dan untuk memasang strainer bagian bawah seperti pada gambar 1a.

- CO dipasang pada lubang yang telah dibuat dan dilas dengan menggunakan las PVC, dan diusahakan agar kuat dan tidak bocor.

- Salah satu dop (tutup) PVC 4" dilubangi pada bagian tengahnya dengan diameter 3/4", dan dipasang sock drat luar dan sock drat dalam, kemudian dilas dengan las PVC agar kuat. Dop tersebut dipasang pada bagian atas filter. Dop atas tersebut juga berfungsi untuk tempat memasang strainer atas.

- Setelah pemasangan CO dan strainer bawah pada pipa filter 4" selesai, dlanjutkan dengan pemasangan dop bawah. Untuk dop bawah dipilih bentuk yang rata agar filter dapat berdiri dengan leluasa. Cara pemasangan dop bawah yakni dengan menggunakan lem PVC setelah kering baru dilas dengan las PVC agar kuat menahan tekanan.

- Setelah pemasangan dop (tutup) bawah selesai, dilanjutkan dengan pemasangan dop atas yang dilengkapi dengan strainer.

- Setelah pemasangan dop atas dan dop bawah selesai, dilanjutkan dengan pemasangan krankran pengatur aliran masuk, aliran keluar, dank kran untuk pencucian balik (back wash) seperti yang ditunjukan pada gambar $1 b$.

TABEL 1. Bahan yang digunakan

\begin{tabular}{|c|l|c|c|}
\hline No & \multicolumn{1}{|c|}{ Nama Bahan } & Unit & Jumlah \\
\hline 1 & Pipa PVC, diameter 4 inc & meter & 1,2 \\
\hline 2 & Dop (tutup) PVC 4 inc & buah & 2 \\
\hline 3 & CO PVC 3 inc & buah & 2 \\
\hline 4 & Stop Kran, 3/4" & buah & 5 \\
\hline 5 & Knee 3/4", PVC & buah & 4 \\
\hline 6 & Sambungan T 3/4", PVC & buah & 4 \\
\hline 7 & Strainer & buah & 2 \\
\hline 8 & Sock Drat Dalam 3/4", & buah & 2 \\
\hline 9 & Sock Drat luar 3/4", PVC & buah & 10 \\
\hline 10 & Water Mur & buah & 2 \\
\hline 11 & Lem Epoxy & buah & 2 \\
\hline 12 & Lem PVC (kaleng) & buah & 1 \\
\hline 13 & Dempul & kg & 1 \\
\hline 14 & Amplas & lembar & 5 \\
\hline 15 & Pipa PVC 3/4" & batang & 1 \\
\hline 16 & Batang Las & batang & 7 \\
\hline 17 & Cat pilox & kaleng & 2 \\
\hline 18 & Seal Tape & buah & 5 \\
\hline 19 & Kerikil diameter 5-8 mm & liter & 3 \\
\hline 20 & Pasir Silika & kg & 20 \\
\hline 21 & Manganese Dioxide & Kg & 20 \\
\hline 22 & Karbon Aktif & Kg & 10 \\
\hline
\end{tabular}



a

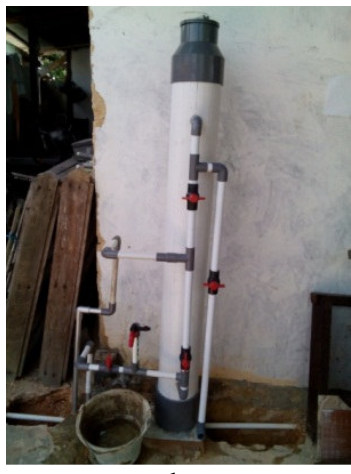

b

GAMBAR 1. Susunan filter bertingkat (a) bentuk skematik; (b) bentuk fisik filter. 
Filter air dibuat terlebih dahulu dengan menggunakan bahan-bahan yang telah disiapkan, seperti batu kerikil, pasir silika, karbon aktif, dan Manganese Dioxide $\left(\mathrm{MnO}_{2}\right)$. Bahan-bahan tersebut dimasukkan ke dalam tabung pipa PVC dengan panjang $130 \mathrm{~cm}$ dan berdiameter 4 inchi dengan urutan batu kerikil paling bawah, pasir silica pada urutan kedua, karbon aktif urutan ketiga, lalu Manganese Dioxide seperti yang ditunjukan pada gambar 2.

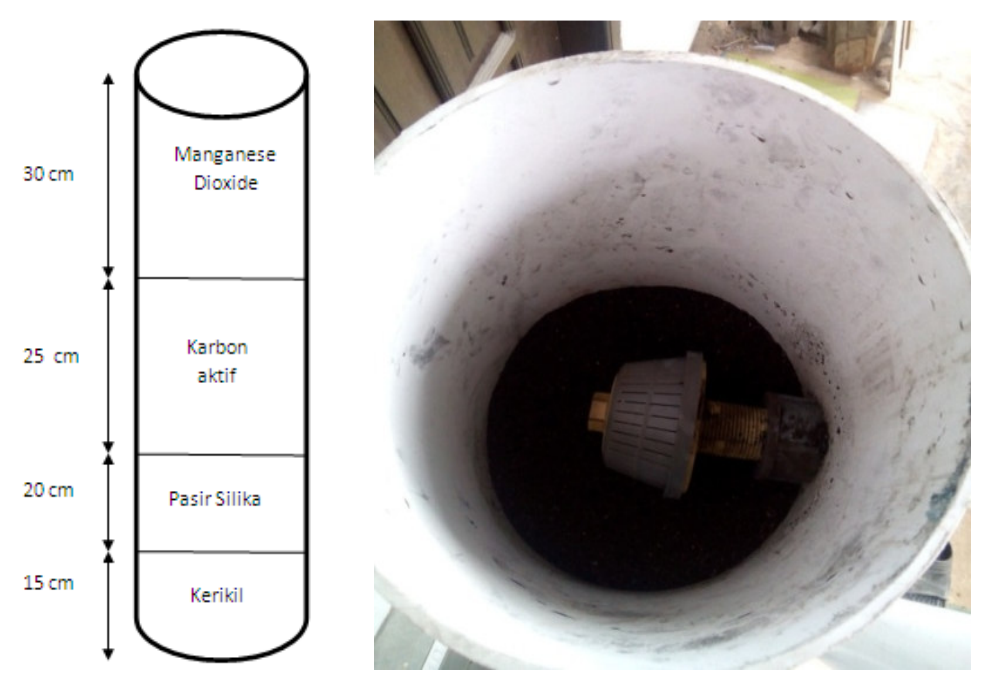

GAMBAR 2. Susunan bahan pengisian filter.

Setelah tabung filter terisi langkah selanjutnya adalah menutup lubang pengisian filter dengan menggunakan dop pipa yang sudah disiapkan,lalu lakukan pengujian kebocoran sebelum filter di instalasikan dengan pipa PDAM. Setelah yakin tidak ada kebocoran kita dapat memasang filter pada pipa air PDAM dan selanjutnya air dialirkan untuk dilakukan pencucian awal media filter selama kurang lebih 10 menit atau sampai air terlihat benar-benar jernih lalu air dapat di alirkan ke pemakaian air minum. Pada pemasangan instalasi perlu diperhatikan bahwa air jangan sampai ada yang bocor. Perlu dilakukan penguatan pada sambungan dengan mengunakan lem pipa sehingga kebocoran dapat diminimalisir. Posisi pipa disesuaikan dengan waterpass sehingga ketinggian dan kemirngan dari pipa setimbang. Hal ini diperlukan guna menjaga aliran agar terfokus ke titik kesetimbangan.

Air dari pipa PDAM dialirkan ke unit filter dengan aliran dari atas ke bawah. Posisi kran pada saat proses penyaringan kran 2 dan 3 ditutup, kran 1 dan 4 dibuka seperti yang ditunjukan posisi sesuai gambar 1a. Air yang telah disaring ditingkatkan kualitasnya dengan cara memasang filter cartridge yang mempunyai diameter rongga 5 mikron pada outlet filter. Setelah melewati filter cartridge air menuju alat pembunuh kuman Ultra Violet (UV Sterilizer) untuk proses sterilisasi agar dapat langsung dimanfaatkan.



GAMBAR 3. Cartridge filter dan Ultra Violet Sterilizer. 
Untuk pencucian filter dapat dilakukan dengan cara pencucian balik (back wash). Prosedurnya adalah dengan mengalirkan air PDAM melalui arah yang berlawanan dengan proses penyaringan yaitu dari bawah ke atas kemudian di buang lewat jalur venting sampai air benarbenar kelihatan jernih. Posisi kran pada saat pencucian filter kran 1 dan 4 ditutup, kran 2 dan 3 di buka posisi kran ditunjukan pada gambar la.

\section{Pengujian Hasil Filter}

Pengambilan sampel dibagi menjadi tiga, sample pertama air di ambil sebelum melewati filter, sample kedua air diambil setelah melewati filter, sample ketiga air diambil setelah melewati filter, Catridge dan sinar UV. Untuk tiap sample baik sample pertama, kedua maupun ketiga sample diambil dengan 2 cawan yg berbeda karena cawan sampel kimia dan sampel mikrobiologi berbeda cara pengambilan dan perlakuannya.

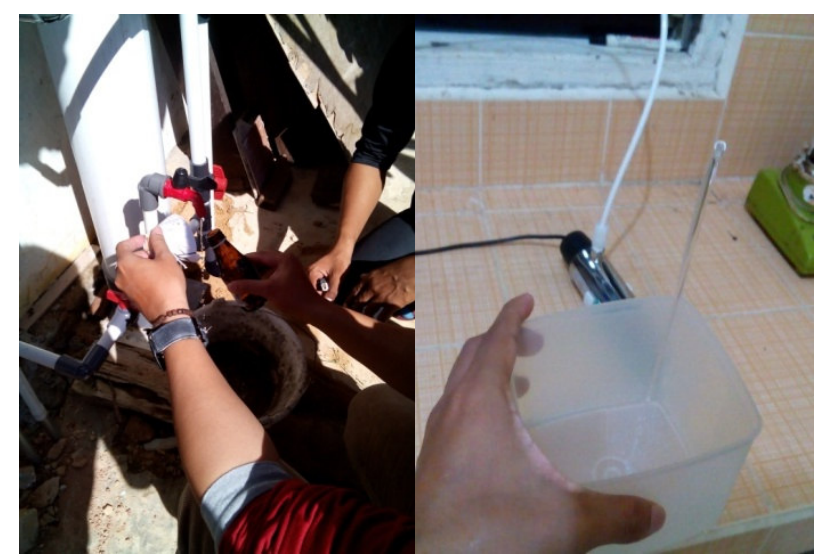

GAMBAR 4. Pengambilan Sampel bahan hasil filter dan hasil sterilisasi.

Pengambilan sampel bahan dilakukan pada saat air PDAM dapat mengalir. Dengan memperhitungkan tekanan maksimal yang diberikan oleh PDAM. Sampel yang pertama yakni air murni dari PDAM sedangkan sampel kedua air yang telah melewati filter air. Gambar 4 menunjukan sampel air yang diperoleh dari filter air yang telah dibuat. Untuk sampel mikrobiologi pada gambar 4 pengambil sample harus terlebih dahulu mencuci tangan dengan alkohol agar tangan benar-benar steril bebas dari bakteri dan kuman, lalu lubang cawan dan lubang kran air harus dibakar terlebih dahulu untuk mensterilkan bakteri lingkungan cawan dan kran setelah itu bilas cawan dengan air sample sebanyak tiga kali lalu ambil sample sampai cawan penuh dan tutup rapat agar tidak ada udara masuk.

Untuk proses pembawaan sample menuju laboratorium yang terpenting adalah sample mikrobiologi harus dijaga temperaturnya agar tetap dingin, untuk itu sample tersebut disimpan didalam box es selama perjalanan menuju laboratorium agar bakteri didalam air tidak berkembang biak dan penelitian di laboratorium bisa mendekati hasil yang akurat. Sedangkan untuk sample kimia tidak ada perlakuan khusus untuk pembawaannya menuju laboratorium.

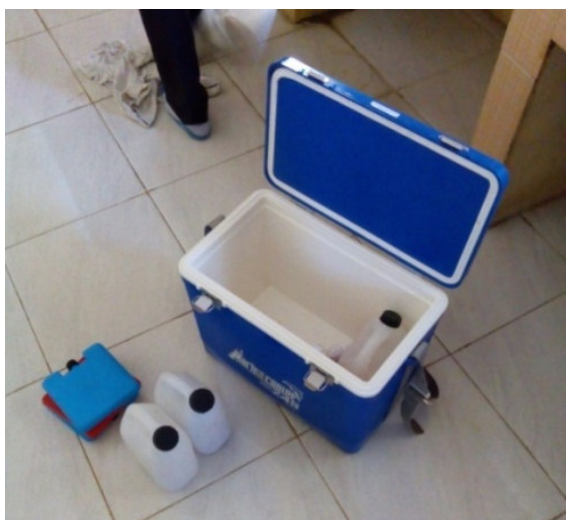

GAMBAR 5. Box es tempat sampel mikrobiologi 


\section{HASIL DAN PEMBAHASAN}

Instalasi filter air dilakukan dengan catride dan UV. Disinfeksi dengan UV pertama kali dilakukan pada permulaan abad ini. Sistem merkuri tekanan rendah yang tertutup dalam tabung querz. Oleh karena itu tabung ini harus dibersihkan secara terjadwal dengan metode mekanik, kimiawi dan ultrasonic. Radiasi UV merusak DNA mikroba pada panjang gelombang $260 \mathrm{~nm}$. Hal ini menyebabkan dimerisasi thymint yang menghalangi replikasi DNA dan efektif menginaktivasi mikroorganisme.

Setelah melalui pengujian alat, air yang telah difilterisasi dicek apakah masih sama atau berbeda dengan air sebelumnya. Untuk lebih memastikannya air diuji di laboratorium. Hasil dari uji laboratorium air tersebut adalah air sudah mengalami penurunan kadar logam serta kotoran lain. Ini berarti salah satu permasalahan yang dihadapi dapat teratasi.

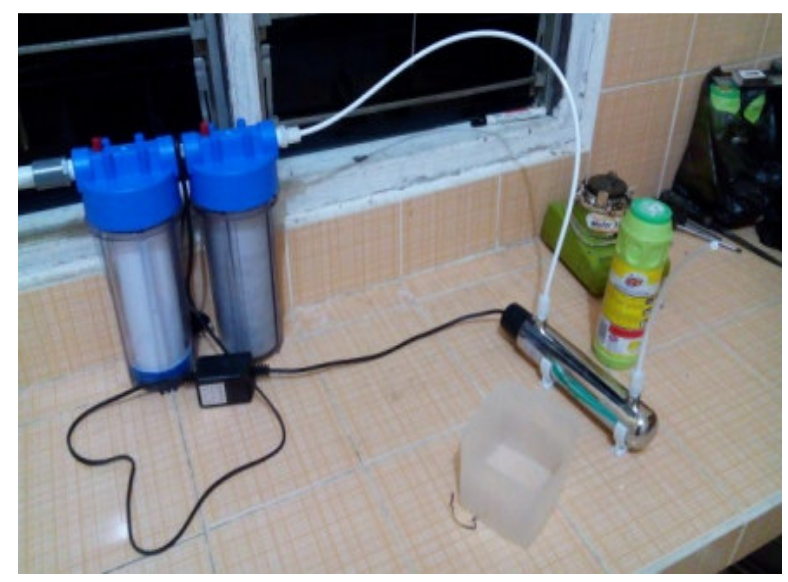

GAMBAR 6. Instalasi catridge dan UV.

Berdasarkan hasil penelitian mengenai pembuatan filter air yang dapat mengubah air PDAM menjadi air siap minum telah diperoleh data-data. Data yang diperoleh digunakan untuk memberikan gambaran tentang pengaruh penambahan filter air dalam pengelolaan air bersih untuk diminum, perbandingan air yang telah di treatment lewat filter dan yang sebelum ditreatment dalam bentuk ditabulasikan secara tabel. Data yang diperoleh berupa data Besi $(\mathrm{Fe})$, mangan (Mn) Kekeruhan (Turbidity), Keasaman (pH), dan mikro bakteri seperti bakteri E. Coli. Dari air yang diuji tersebut diperoleh data seperti pada tabel 2.

TABEL 2. Data Hasil Uji Pengambilan Sampel bahan baku Setelah Proses Filter

\begin{tabular}{|l|c|c|c|c|c|}
\hline \multirow{2}{*}{ Bahan Uji } & \multirow{2}{*}{ Satuan } & \multicolumn{3}{|c|}{ Sampel } & \multirow{2}{*}{ Standar Baku } \\
\cline { 3 - 5 } & & 1 & 2 & 3 & \\
\hline Kekeruhan & $\mathrm{NTU}$ & 9,73 & 4,01 & 1,56 & 5 \\
\hline Besi (Fe) & $\mathrm{mg} / \mathrm{l}$ & 8,6 & 0,28 & 0,086 & 0,3 \\
\hline Mangan $(\mathrm{Mn})$ & $\mathrm{mg} / \mathrm{l}$ & 4,8 & 0,15 & 0,06 & 0,1 \\
\hline Total Bakteri Coli & $\mathrm{MPN} / \mathrm{ml}$ & $>1600$ & $>1600$ & 0 & 0 \\
\hline
\end{tabular}

Dari tabel 2 diatas terlihat 3 hasil uji laboratorium antara air yang belum melalui filterisasi,air setelah melalui filtrasi,dan air setelah melewati catridge dan sinar UV. Data hasil pengujian akan dibandingkan kualitas air sebelum melewati filter dengan air setelah melalui tahap penyaringan. Data setelah melewati proses pemurnian tersebut akan dibandingkan dengan PERMENKES 2010 tentang standar baku air minum untuk dapat di tarik kesimpulan apakah air tersebut layak untuk di komsumsi atau tidak .

Setelah melalui pengujian alat, air yang telah difilterisasi dicek apakah masih sama atau berbeda dengan air sebelumnya. Untuk lebih memastikannya air diuji di laboratorium. Hasil dari uji laboratorium air tersebut adalah air sudah mengalami penurunan kadar logam serta kotoran lain. Itu berarti salah satu permasalahan yang dihadapi dapat teratasi. Dari data yang diperoleh dapat disajikan dalam bentuk grafik seperti pada gambar 7 . 




Hasil pengamatan dilaboratorium dilakukan dengan tiga sampel untuk pengujian kadar besi $(\mathrm{Fe})$. Sampel pertama diukur sebelum air PDAM masuk pada filter air. Diperoleh kadar besi (Fe) sebesar 8,6 mg/l yang mengisyaratkan bahwa kualitas air tidak dapat untuk diminum. Sampel kedua diukur setelah melewati filter air diperoleh kadar besi $(\mathrm{Fe})$ sebesar $0,28 \mathrm{mg} / 1$ yang mengisyaratkan bahwa kualitas air sudah dapat dipenuhi standar untuk besi sebsar 0,30 mg/l. Pada sampel ketiga setelah melewati catride dan sinar UV diukur kadar Fe sebesar 0,086 $\mathrm{mg} / \mathrm{l}$. Nilai ini sangat baik sebagai kualias air minum.

Hasil pengamatan dilaboratorium dilakukan dengan tiga sampel untuk pengujian kadar Mangan (Mn). Sampel pertama diukur sebelum air PDAM masuk pada filter air. Diperoleh kadar Mangan (Mn) sebesar 4,8 mg/l yang mengisyaratkan bahwa kualitas air tidak dapat untuk diminum. Sampel kedua diukur setelah melewati filter air diperoleh kadar mangan (Mn) sebesar $0,15 \mathrm{mg} / \mathrm{l}$ yang mengisyaratkan bahwa kualitas air sudah dapat dipenuhi standar untuk mangan sebesar $0,4 \mathrm{mg} / \mathrm{l}$. Pada sampel ketiga setelah melewati catride dan sinar UV diukur kadar Fe sebesar $0,4 \mathrm{mg} / \mathrm{l}$. Nilai ini sangat baik sebagai kualias air minum.

Hasil pengamatan dilaboratorium dilakukan dengan tiga sampel untuk pengujian kadar kekeruhan. Sampel pertama diukur sebelum air PDAM masuk pada filter air. Diperoleh kadar kekeruhan sebesar 9,73 NTU yang mengisyaratkan bahwa kualitas air tidak dapat untuk diminum. Sampel kedua diukur setelah melewati filter air diperoleh kadar kekeruhan sebesar 4,01 NTU yang mengisyaratkan bahwa kualitas air sudah dapat dipenuhi standar untuk kekeruhan sebesar 5 NTU. Pada sampel ketiga setelah melewati catride dan sinar UV diukur kadar kekeruhan sebesar 1,56 NTU. Nilai ini sangat baik sebagai kualias air minum.

Pada pengamatan dilaboratorium untuk menentukan jumlah bakteri yang terkandung dalam sampel air. Pada sampel pertama sebelum masuk filter kondisi jumlah bakteri di atas $>1600$ MPN/ml. Ukuran ini diperoleh dikarenakan ini air yang belum masuk filter dan masih konsisi air PDAM. Setelah melewati filter kondisi bakteri masih diatas $>1600 \mathrm{MPN} / \mathrm{ml}$. Hal ini disebabkan hasil filter belum dilakukan pembunuhan bakteri. Setelah melewati catride UV barulah diperoleh jumlah bakteri $0 \mathrm{MPN} / \mathrm{ml}$ yang mengisyaratkan air telah sesuai syarat sebagai air minum untuk standar jumlah bakteri. Disifektan ini efisien untuk menghilangkan virus yang merupakan substansi utama penyebar penyakit air dari sumber air tanah. Dengan dosis tertentu UV mengurangi bakteri dalam 20 menit pada hasil filter.

\section{KESIMPULAN}

Dari penelitian diperoleh proses filtrasi melalui media kerikil,pasir silica, karbon aktif, dan manganese dioxide mampu mengurangi kandungan besi,mangan, dan kekeruhan. Hasil yang diperoleh kadar besi $(\mathrm{Fe})$ menjadi $0,28 \mathrm{mg} / 1$ yang semula $8,6 \mathrm{mg} / 1$, kadar mangan $0,15 \mathrm{mg} / 1$ yang semula 4,8 mg/l dan kadar kekeruhan 4,01 NTU yang semula 9,73 NTU. Pada proses filtrasi ini belum mampu untuk menghilangkan bakteri E.coli dimana masih berkisar lebih dari $1600 \mathrm{MPN} / \mathrm{ml}$. Pada tahap ketiga dari filter ini dengan penambahan catridge dan sinar UV tampak bahwa bakteri E.Coli telah mati. Pada tahap ketiga dari pembuatan alat filter ini pula diperoleh kadar besi $(\mathrm{Fe})$ 0,086 mg/l, mangan $(\mathrm{Mn}) 0,06 \mathrm{mg} / 1$, dan kekeruhan 1,56 NTU. Nilai dari ke empat parameter yakni kekeruhan, besi (Fe), mangan (Mn) dan bakteri E.coli telah dibawah standar baku mutu air yang dipersyaratkan untuk komsumsi. 


\section{REFERENSI}

[1] Yudo, Satmoko., dan P. Nugro Rahardjo. (2005) . Evaluasi Teknologi Air minum Isi Ulang di DKI Jakarta. JAI Vol. 1 No.3 2005.

[2] Sadtim. (2009). Pengadaan Air Minum di Permukaan Daerah Rawa. Rekayasa Sipil. Vol. 5 No. 1 April, ISSN 1858-3695

[3] Alegantina, Sukmayanti., Ani Isnawati, dan Mariana Raini. (2009). Gambaran Kualitas Air minum Di Jabodetabek Tahun 2007-2009. Jurnal Kefarmasian Indonesia No. 1 Vol. 3

[4] Widayat, Wahyu. (2005). Teknologi Pengolahan Air Siap Minum Untuk Daerah Padat Penduduk. Jurnal Air Indonesia. Vol.1 No.2

[5] Said, Nusa idaman. (2005). Metoda Penghilangan Zat Besi dan Mangan di Dalam Penyediaan Air Minum Domestik. Jurnal Air Indonesia. Vol. 1 No.3

[6] Wong, J.M., (1984). Chlorination-fitration for iron and maganese Removal. Journal AWWA Vol. 76. No. 1 Januari 1984

[7] Mifbakhudin, Ratih Sari Wardani, Atfis Prihandono Rozaq. (2008). Pengaruh ketebalan diameter Ziolit digunakan sebagai media filter terhadap penurunan kesadahan air sumur artetis. Jurnal Kesehatan Masyarakat Indonesia Vol 4, No 2 (2008): Public Health Vol. 4 No. 2

[8] Nurhasmi, Junaedi subaer, nurhayati. (2015). Pengembangan Geopolimer Berbasis Karbon Aktif Sebagai Keramik Filter Ganda Untuk Aplikasi Air Sumur. Jurnal Sains dan Pendidikan Fisika Vol. 11 No. 3 hal 280-285. Universitas Negeri Makassar.

[9] Wahyudin, Rachmat Triandi Thahjanto, Sri Wardhani. 2013. Kombinasil Ozonisasi, Iradiasi Ultraviolet dan zaolit untuk disinfeksi air tanah dan penentuan konsentrasi ozon dengan metode Spektrofotometeri UV-Visible. Kimia Student Journal. Vol. 1 No.1 pp. 126-132 Universitas Brawijaya Malang.

[10] Arya Rezagama. 2013. Studi Ozonisasi Senyawa Organik Air Lindi Tempat Pemrosesan Akhir Sarimukti. Jurnal Teknik Vol. 34 No.2 hal. 82-87 Fakultas Teknik Universitas Diponegoro 